\title{
An Investigation of Master Student Understanding on Mathematical Literacy Problems
}

\author{
Al Jupri ${ }^{{ }^{*}}$, Rizky Rosjanuardi ${ }^{2}$ \\ ${ }^{1,2}$ Universitas Pendidikan Indonesia, Bandung, Jawa Barat, 40154, Indonesia \\ Pengiriman: 17/Desember/2019; Diterima: 24/Maret/2020; Publikasi: 31/Maret/2020 \\ DOI: https://doi.org/10.31629/jg.v5i1.1828
}

\begin{abstract}
Abstrak
Pemerintah Indonesia telah menggalakkan Gerakan Literasi Nasional sejak tahun 2016 untuk merespon hasil mengecewakan dari studi Program for International Student Assessment tentang kemampuan literasi dan literasi matematis siswa Indonesia. Gerakan ini melibatkan banyak pihak, termasuk universitas kependidikan, untuk menyiapkan mahasiswa pendidikan matematika tingkat magister, sebagai calon guru atau dosen, untuk memahami literasi matematis. Untuk menyelidiki kondisi ini, penelitian ini bertujuan untuk menganalisis pemahaman mahasiswa magister terhadap soal-soal literasi matematis. Untuk itu, dilakukan survei online melalui Google Form melibatkan 32 mahasiswa magister dari beberapa universitas di Bandung. Dalam survei ini, setiap peserta diminta mengirim dua soal matematika dan jawabannya yang dipandang sebagai masalah literasi matematis. Hasil survei menunjukkan bahwa hanya $17(53 \%)$ mahasiswa yang terlibat memahami dengan benar soal-soal literasi matematis. Kategori soal literasi yang paling sering muncul dari para mahasiswa tersebut adalah kategori Change and Relationship, diikuti secara berurutan oleh kategori Space and Shape, Uncertainty and Data, dan Quantity. Hasil lain yang ditemukan adalah bahwa soal cerita tampaknya dianggap sama dengan soal literasi matematis oleh sebagian mahasiswa yang terlibat. Kami menyimpulkan bahwa pemahaman mahasiswa magister pendidikan matematika terhadap literasi matematis perlu ditingkatkan untuk bekal mereka menghadapi karir bidang pendidikan di masa depan.
\end{abstract}

Kata kunci: pendidikan matematika; literasi matematis; keterampilan literasi matematis; soal-soal literasi matematis

\begin{abstract}
Indonesian government has been promoting the National Literacy Movement since 2016 to response disappointing results of the Program for International Student Assessment on literacy and mathematical literacy skills of students. This movement involves many parties, including educational universities, to prepare mathematics education students of master level, as prospective teachers or lecturers, to understand mathematical literacy. To investigate this condition, this study aims to analyze master student understanding on mathematical literacy problems. To do so, we conducted an online survey via Google Form involving 32 master students from several universities in Bandung. In this survey, each master student was called for sending two mathematics problems and solutions that considered to be literacy problems. The results revealed that $17(53 \%)$ involved master students understand mathematical literacy problems. The most frequent category of literacy problems to appear was Change and Relationship followed by categories of Space and Shape, Uncertainty and Data, and Quantity, respectively. Another result showed that word problems seemed to be regarded the same as mathematical literacy problems by
\end{abstract}

*Corresponding author 


\section{JURNAL GANTANG. Maret 2020; V(1): 1-7 \\ p-ISSN. 2503-0671 \\ e-ISSN. 2548-5547}

some students. We conclude that master student understanding on mathematical literacy need to be improved for facing future educational careers.

Keywords: mathematics education; mathematical literacy; mathematical literacy skills; mathematical literacy problems

\section{Introduction}

An important issue about low mathematical literacy skills of Indonesian students (15-16 year-old) has been discussed by academicians, government, and stakeholders since at least a decade ago in response to the disappointing results of the Program for International Student Assessment (PISA) (Tjalla, 2010). The current results of this PISA study however showed that Indonesian students' mathematical literacy scores, from 2009 to 2018, are still about 360 to 386 , which are very low compared to international average of 500 (OECD, 2010, 2013, 2014, 2016, 2019) To verify these disappointing results, Indonesian government has carried out a similar study using Indonesian contexts: the result revealed that Indonesian students in different cities are having really low and varied mathematical literacy skills (Mahdiansyah \& Rahmawati, 2014). A study carried out by Setiawati, Herman, and Jupri (2017) for investigating students' mathematical literacy skills also showed a disappointing result, i.e., in general, students are only able to solve mathematics problems using simple and routine procedures.

In response to the results of national and international studies above, since 2016 Indonesian government has been promoting Gerakan Literasi Nasional (Indonesian Literacy Movement), including numeracy or mathematical literacy (Kemdikbud, 2017). This movement should be supported by relevant stakeholders including educational universities for, for instance, preparing readiness of mathematics education students of master level-as prospective mathematics teachers or lecturers - on the understanding of mathematical literacy.
To get an insight into master students' readiness on mathematical literacy, this study aims to analyze these students' understanding on mathematical literacy problems. Through this study we would get benefit for, for instance, improving the quality of mathematics education in Indonesia, and in particular for improving the quality of prospective mathematics teachers and lecturers.

As a framework to do the analysis, we use the definition of mathematical literacy according to PISA, and the PISA framework of mathematics content domain (OECD, 2013). PISA defines mathematical literacy as follows:

Mathematical literacy is an individual's capacity to formulate, employ, and interpret mathematics in a variety of contexts. It includes reasoning mathematically and using mathematical concepts, procedures, facts, and tools to describe, explain, and predict phenomena. It assists individuals to recognize the role that mathematics plays in the world and to make the well-founded judgments and decisions needed by constructive, engaged and reflective citizens (OECD, 2013).

The term 'literacy' in mathematical literacy is not only restricted to indicating a basic, minimum level of functionality, but it is also a continuous, multidimensional spectrum ranging from aspects of basic functionality to high-level mastery (De Lange, 2006). Mathematics contents in PISA (De Lange, 2006; OECD, 2013; Stacey, 2011) are clasified into four categories below:

\section{- Change and Relationship}

A natural phenomenon can be described as a manifestation of change, and relationships between natural phenomena can be modelled by mathematical relationships. Some of these change processes can be modelled by mathematical functions: linear or exponential, 
periodical or logistic. While mathematical relationships that often useful to describe connection between phenomana include equations and inequalities. In short, the category of Change and Relationship represents mainly the domain of algebra.

- Space and Shape

This category includes a wide range of phenomena in our visual and physical world: patterns, properties of objects, positions and orientations, representations of objects, decoding and encoding of visual information, navigation and dynamic interaction with real shapes as well as with representations. This category mainly represents the domain of geometry.

- Quantity

This category, mainly representing the domain of numbers, includes quantification of attributes of objects, relationships, situations and entities; understanding various representations of quantifications; and judging interpretations and arguments based on quantity. In addition, it also covers understanding measurements, counts, magnitudes, units, indicators, relative size, and numerical trends and patterns. In other words, this category concerns aspects of quantitative reasoning, such as number sense, multiple representations of numbers, elegance in computation, mental calculation, estimation and assessment of reasonableness of results.

\section{- Uncertainty and Data}

This category, mainly representing the domain of probability and statistics, includes recognising the place of variation in processes, having a sense of the quantification of that variation, acknowledging uncertainty and error in measurement, and knowing about chance. It also includes forming, interpreting and evaluating conclusions drawn in situations where uncertainty is central.

\section{Methods}

We conducted an online survey study via
Google Form to investigate master students' understanding on mathematical literacy problems. The Google Form can be accessed at http://bit.ly/calongurumatematika. The survey was part of registration form for attending a workshop on the development of mathematical literacy problems for master students in the field of mathematics education. In this survey, each master student participant was requested to fill in his/her identity, undergraduate education background, and to send two mathematics problems and solutions that are considered to be mathematical literacy problems.

Out of the 38 online registered participants, 32 master students sent 64 mathematics problems that are considered to be mathematical literacy problems. All master student participants came from universities in Bandung area.

In the analysis, first, we determined whether the mathematics problems are literacy problems or not. Second, using the PISA framework of mathematical contents (OECD, 2013), we identified whether a mathematics problem can be classified into the category of Change and Relationship (CR), Quantity (Q), Space and Shape (SS), or Uncertainty and Data (UD). This categorization is done to investigate mathematics domains that master students tend to be capable for understanding mathematical literacy problems. Third, based on these two first steps, we decided that a master student who sent correct literacy problems and solutions is considered to have good understanding on mathematical literacy problems.

\section{Results and Discussion}

Table 1 presents the result of analysis toward mathematics problems sent by master students. Column 1 presents classification of mathematics problems into literacy and nonliteracy problems. Columns 2-5 present the number of mathematics content categories (\#CR, \#SS, \#Q, \#UD) and the corresponding percentages. 


\section{JURNAL GANTANG. Maret 2020; V(1): 1-7 \\ p-ISSN. 2503-0671 \\ e-ISSN. 2548-5547}

Of the 64 mathematics problems sent by the master students, 34 problems (53\%) are mathematical literacy problems and the rests are ordinary school mathematics problems. This means that about a half the number of the participated master students understands mathematical literacy problems. We observed that the sources of the 34 literacy problems are varied: most of the problems are adapted from PISA released items and some other problems stem from students' own creations. We conjecture that master students who sent correct mathematical literacy problems have good understanding about mathematical literacy, probably because they have already been familiar with, for instance, the PISA study in their previous schooling.

Table 1.

Results of analysis on mathematics problems

\begin{tabular}{llllll}
\hline $\begin{array}{l}\text { Type of } \\
\text { Problems }\end{array}$ & $\begin{array}{l}\text { \#CR } \\
(\%)\end{array}$ & \#SS (\%) & \#Q (\%) & $\begin{array}{l}\text { \#UD } \\
(\%)\end{array}$ & $\begin{array}{l}\text { Total } \\
(\%)\end{array}$ \\
\hline $\begin{array}{l}\text { \#Literacy } \\
\text { Problems }\end{array}$ & $11(17.1)$ & $8(12.5)$ & $6(9.3)$ & $9(14.1)$ & $34(53)$ \\
\hline $\begin{array}{l}\text { \#Non- } \\
\text { literacy } \\
\text { Problems }\end{array}$ & $13(20.3)$ & $13(20.3)$ & $2(3.2)$ & $2(3.2)$ & $30(47)$ \\
\hline $\begin{array}{l}\text { Total } \\
(\%)\end{array}$ & $24(37.4)$ & $21(32.8)$ & $8(12.5)$ & $11(17.3)$ & $64(100)$ \\
\hline
\end{tabular}

From the perspective of mathematics content categories, we found that the Change and Relationship (CR) is the most frequent category of mathematics problems sent by the students: of the 64 problems, 24 problems (37.4\%) are in the category of Change and Relationship. The second and the third most frequent categories to appear are Space and Shape and Uncertainty and Data categories. The category of Quantity (Q) is the least frequent to appear $(12.5 \%)$ in the problems.

If we scrutinize into mathematical literacy problems only, still the category of Change and Relationship is the most frequent $(17.1 \%)$ and the category of Quantity is the least frequent $(6.3 \%)$ to appear. The second and the third most frequent categories to appear are Uncertainty and Data and Space and Shape categories.

The above findings suggest that most of master students seem to have more capacity, generally speaking, to the domain of algebra. This seems to be caused by the fact that the Indonesian school mathematics curriculum for secondary schools is dominated by the algebra domain (Depdiknas, 2006; Kemdikbud, 2013).

Even if the category of Change and Relationship be the most frequent to appear, we not only can analyze literacy problems in this category (Zulfitri et al., 2019), but also can explore the development of problems in this category. The fact that the category of Quantity is the least frequent to appear in our survey can be an opportunity either for developing problems in this category (Bidasari, 2017), or for conducting further exploration.

To illustrate how we decided whether a mathematics problem is a literacy problem or not, and to what category the problem is included, we illustrate with the following two examples. As the first example, consider a mathematics problem presented in Figure 1. This problem is considered a non-literacy problem because it is a routine school mathematics problem in the topic of application of the set concept (Budhi, 2006). Also, even if the problem is in the form of word problem (Jupri \& Drijvers, 2016), the context does not provide sufficient reasons why we should solve the problem.

In a village named as Jaya, there are 77 families. Of these, 29 families have motorcycles, 21 families have cars, and 13 families have both cars and motorcycles. How many families who have no cars or motorcycles?

Figure 1. An example of non-literacy problems

A routine procedure for solving the problem in Figure 1 might look like in Figure 2. From this solution, we observe that equationswhich represent relationships between information given in the problem-are main elements in the solution process. Therefore, according to aforementioned framework (De Lange, 2006; OECD, 2013; Stacey, 2011), we assign this problem into the category of Change 
and Relationship.

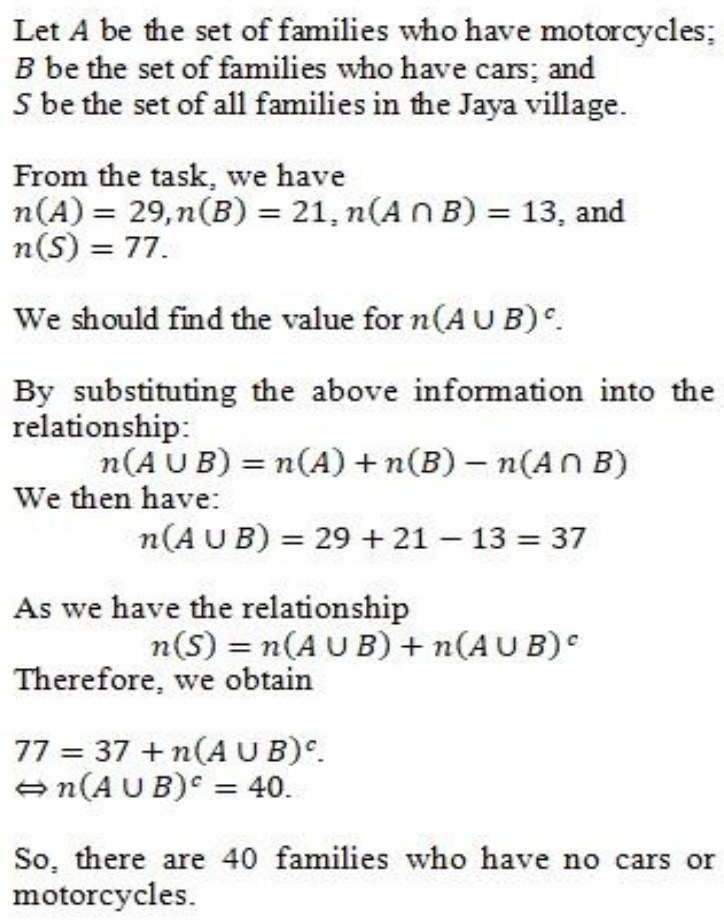

So, there are 40 families who have no cars or motorcycles.

Figure 2. Solution to the problem in Figure 1

For the second example, we consider the problem in Figure 3 to be a literacy problem with the following reasons. The problem contains realistic context that is meaningful for students. By 'realistic' context we mean students can imagine the context of Asian Games (Jupri, 2017; Van den Heuvel-Panhuizen \& Drijvers, 2014) and can understand the need for doing exercise before this big event. This context, therefore, indirectly supports students to use their mathematical repertoire of knowledge, such as numbers, exploring data and information, and mathematical reasoning, to solve the problem.

To prepare for the 2018 Asian Games, karate athletes namely Faisal, Hendro, Salim, Iwan, Ahmadi, and Fidelys have formed a training club. Each athlete will fight each other once only. To do this exercise, they have prepared three mattresses. Please make a schedule of match practice by writing the names of the players who are playing in each round and each mattress must be filled in with players' name.

Figure 3. An example of literacy problems

An alternative solution to this problem is presented in Figure 4. In this solution process, a student should explore the solution by, for instance, creating a table to tabulate all possible schedules between the two out of six athletes, with the requirement that every two athletes only meet once. The process of exploring these data and information is uncertain. Based on this consideration and according to the framework (OECD, 2013), we classified this problem into the category of Uncertainty and Data.

\begin{tabular}{|l|l|l|l|}
\cline { 2 - 4 } \multicolumn{1}{c|}{} & \multicolumn{1}{c|}{ Mattress 1 } & \multicolumn{1}{c|}{ Mattress 2 } & \multicolumn{1}{c|}{ Mattress 3 } \\
\hline Round 1 & Faisal \& Hendro & Salim \& Iwan & Ahmad \& Fidelys \\
\hline Round 2 & Faisal \& Salim & Iwan \& Ahmad & Hendro \& Fidelys \\
\hline Round 3 & Faisal \& Iwan & Salim \& Fidelys & Ahmad \& Hendro \\
\hline Round 4 & Faisal \& Ahmad & Salim \& Hendro & Iwan \& Fidelys \\
\hline Round 5 & Faisal \& Fidelys & Iwan \& Hendro & Ahmad \& Salim \\
\hline
\end{tabular}

Figure 4. An alternative solution for the problem in Figure 3

In addition to the above findings, we found that of the 64 problems, 62 problems are word problems and all 34 mathematical literacy problems are word problems. These findings suggest that, to some extent, literacy problems seems to be regarded as the same as word problems. Even if this consideration is incorrect, this is probably caused by the fact that word problems often contain daily life contexts, application of mathematical concepts (Toom, 1999), and mathematization process (Jupri \& Drijvers, 2016), which are similar to mathematical literacy problems.

\section{Conclusions}

From the description of results and discussion in previous section, we draw the following three conclusions. First, we found that only about half the number of master students in mathematics education - as prospective mathematics teachers or lecturers-can pose correct mathematical literacy problems. This result indicates about a lack of master student understanding on mathematical literacy problems. This finding also suggests that educational universities should do more effort to provide proper understanding about mathematical literacy to mathematics education students. The efforts can be in the form of, for 


\section{JURNAL GANTANG. Maret 2020; V(1): 1-7 \\ p-ISSN. 2503-0671 \\ e-ISSN. 2548-5547}

instance, socialization and integrating the idea of mathematical literacy in relevant mathematics education courses.

Second, from further analysis on mathematics and mathematical literacy problems sent by master students, we found that the category of Change and Relationship is the most frequent to appear, followed respectively by the categories of Space and Shape, Uncertainty and Data, and Quantity. This finding might indicate that master students involved in this study are more favored to or more masterful to the domain of algebra which represents the category of Change and Relationship. For further investigation, for instance, with larger number of subjects, we wonder whether this finding is confirmed. Also, we wonder whether this result is influenced by some educational courses addressing literacy problems on the category of Change and Relationship.

Finally, the third, we found that all mathematical literacy problems in this study are in the form of word problems. Therefore, we should emphasize that these two types of problems (literacy and word problems) share not only similarities, but also differences. Mathematics word problems that popularly appear in school mathematics textbooks, in which the procedure for solving them are already known, might not be classified into mathematical literacy problems. Whereas mathematics word problems having meaningful contexts that provide reasons for solutions and invite the use of repertoire knowledge of mathematics to formulate, employ, and interpret mathematics in a variety of contexts (OECD, 2013) can be regarded as mathematical literacy problems. Taking this into account, we suggest a further investigation to compile characteristics of mathematical literacy problems. In this way, determining whether a mathematics problem is truly mathematical literacy problem or not becomes easier.

\section{Acknowledgments}

This study was funded by the program of Pengabdian Kepada Masyarakat Sekolah
Pascasarjana year 2019, Universitas Pendidikan Indonesia, with the Rector Decree No. 4857/UN40/2019. We thank all involved master students for their active participation in this study. We also thank Muh. Khaedir Lutfi, S.Pd. Gr. and his team for their help during data collection.

\section{References}

Bidasari, F. (2017). Pengembangan soal matematika model PISA pada konten Quantity untuk mengukur kemampuan pemecahan masalah matematika siswa Sekolah Menengah Pertama. Jurnal Gantang, 2(1), 63-77.

Budhi, W. S. (2006). Matematika untuk SMP kelas VII semester 2. Jakarta: Erlangga.

De Lange, J. (2006). Mathematical literacy for living from OECD-PISA perspective. Tsukuba Journal of Educational Study in Mathematics, 25(1), 13-35.

Depdiknas. (2006). Kurikulum tingkat satuan pendidikan sekolah menengah pertama. Jakarta: Departemen Pendidikan Nasional.

Jupri, A. (2017). Pendidikan matematika realistik: Sejarah, teori, dan implementasinya. In Bunga rampai kajian pendidikan dasar: Umum, matematika, bahasa, sosial, dan sains (pp. 85-95). Bandung: UPI Press.

Jupri, A., \& Drijvers, P. (2016). Student difficulties in mathematizing word problems in algebra. Eurasia Journal of Mathematics, Science and Technology Education, 12(9), 2481-2502.

Kemdikbud. (2013). Kurikulum 2013. Kompetensi Dasar: Sekolah Menengah Pertama (SMP)/Madrasah Tsanawiyah (MTs). Jakarta: Kementerian Pendidikan dan Kebudayaan.

Kemdikbud. (2017). Materi Pendukung Literasi Numerasi: Gerakan Literasi Nasional. Jakarta: Kementerian Pendidikan dan Kebudayaan.

Mahdiansyah, M., \& Rahmawati, R. (2014). Literasi matematika siswa pendidikan menengah: Analisis menggunakan desain tes internasional dengan konteks Indonesia. Jurnal Pendidikan Dan Kebudayaan, 20(4), 452-469.

OECD. (2010). PISA 2009 Result: What students know and can do: Student performance 
in reading, mathematics, and science.

Paris: OECD Publishing.

OECD. (2013). PISA 2012 assessment and analytical framework: Mathematics, reading, science, problem solving and financial literacy. Paris: OECD Publishing.

OECD. (2014). PISA 2012 Result: What students know and can do. Paris: OECD Publishing.

OECD. (2016). PISA 2015 technical report. Paris: OECD Publishing.

OECD. (2019). PISA 2018 results: Combined executive summaries Volume I, II, \& III. Paris: OECD Publishing.

Setiawati, S., Herman, T., \& Jupri, A. (2017). Investigating middle school students' difficulties in mathematical literacy problems level 1 and 2. Journal of Physics: Conference Series, 909(1), 1-9.

Stacey, K. (2011). The PISA view of mathematical literacy in Indonesia. Journal on Mathematics Education, 2(2), 95-126.

Tjalla, A. (2010). Potret mutu pendidikan Indonesia ditinjau dari hasil-hasil studi internasional. Repository.Ut.Ac.Id, 1-22.

Toom, A. (1999). Word problems: Applications or mental manipulatives. For the Learning of Mathematics, 19(1), 36-38.

Van den Heuvel-Panhuizen, M., \& Drijvers, P. (2014). Realistic Mathematics Education. In Encyclopedia of Mathematics Education (pp. 521-525). Springer.

Zulfitri, H., Aisyah, N., \& Indaryanti, I. (2019). Analisis kemampuan pemecahan masalah matematika setelah pembelajaran dengan pendekatan MEAs pada materi sistem persamaan linier tiga variabel. Jurnal Gantang, 4(1), 7-13. 